\title{
What Determines the Behavior of Exchange Rate in Pakistan: Monetary Model Analysis?
}

\author{
Mr. Junaid Abbasi, Dr. Sadia Safdar \\ Lecturer Indus College of Science \& Commerce 74-E Jinnah Avenue, Blue Area Islamabad \\ Assistant Professor FUUAST, School of Economic Sciences Federal Urdu University of Arts, Science and \\ Technology, Islamabad.
}

\begin{abstract}
Main objective of our study is to determine the exchange rate through the monetary model and modify the monetary model by using the annual time series data from 1982-2009. The results show that dollarization plays an important role in the determination of exchange rate so we should focus on the modified monetary instead of simple model. Thus exchange rate policy has to be selected taking into account high degree of dollarization.
\end{abstract}

Key Words: Exchange Rate, Monetary Model, Dollarization, Cointegration Test, Short Run Analysis

\section{Introduction:}

The issue of exchange rate determination has been recently in the core of academic debates. Despite the fact that many exchange rate determination models and their modifications have been developed, economists still cannot agree on which model best describes behavior of exchange rate and because empirical tests of the models are often ambiguous and sometimes even contradictory. The empirical evidence defeating conventional monetary theories of exchange rate determination for developed world puzzled many economists and caused further theoretic development. At that, existing models have been tested mainly for developed and developing countries while transition countries have not received as much attention.

In the era of globalization and financial liberalization, exchange rate plays an important role in international trade and finance for a small open economy like Pakistan. This is because movements in exchange rates affect the profitability of multinationals and increase exchange exposure to enterprises and financial institutions. A stable exchange rate may help enterprise and financial institutions in evaluating the performance of investments, financing and hedging and thus reducing their operational risks (Nieh and Wang, 2005; Rahman and Hossain 2003). Fluctuations in the exchange rate may have a significant impact on the macroeconomic fundamentals such as interest rates, prices, wages, unemployment, and the level of output. This may ultimately results in a macroeconomic disequilibrium that would lead to real exchange rate devaluation to correct for external imbalances (Parikh and Williams, 1998). Purchasing power parity (PPP) is the most fundamental and controversial hypotheses in international finance through which the long-run equilibrium exchange rate can be explained. It serves as a benchmark for computing equilibrium exchange rate and assessing whether shocks to the real exchange rate dampen over time. This makes the PPP theory as an attractive theoretical and empirical tool for understanding the fluctuations in exchange rate over time.

Monetary models of nominal exchange rate determination were a mainstay of international economics in the 1970s, and the key relationships continue to form an important part of current international macro models. These models appeared to fit in-sample empirical estimations fairly well. Nonetheless, the models were dealt a severe blow by the seminal work of Meese and Rogoff (1983). Using a set of post Bretton Woods's exchange rates for several major industrial countries, Meese and Rogoff showed that a simple random walk had more outof-sample predictive power than the monetary models, even when the future realizations of the explanatory variables in the monetary models were used to generate the out-of-sample forecast.

Subsequent authors tried to overturn these results, but any promising findings turned out to be fragile and the literature has remained pessimist about the link between exchange rates and monetary fundamentals (Frankel and Rose, 1995; Rogoff, 1999).

A recent resurgence of empirical work tries to evaluate exchange rate models using new methods for in-sample and out-of-sample evaluation. With advances in the econometrics of no stationary data, in-sample analysis has turned to co integration to look for long-run relationships between exchange rates and fundamentals. Evidence for co integration has been mixed, with results depending on the country and sample used. For example, MacDonald and Taylor (1993) provide early favorable evidence for co integration between nominal exchange rates and monetary fundamentals for the U.S. dollar-Deutche Mark exchange rate. Rapach and Wohar (2002) use data for 14 industrial countries that span as long as 115 years (1880-1995), and find some 
evidence of co integration for 8 of the 14 countries. Very recent work focuses on using panel co integration tests to take advantage of the power of using multiple country exchange rates and fundamentals. Husted and MacDonald (1998) find evidence of co integrating relationships in panel data sets for the US dollar, German mark and Japanese yen exchange rates using annual data for the recent floating experience. Motivated by the idea of co integration between variables, the recent out-of-sample analysis examines whether the current deviation of the exchange rate from its long-run equilibrium is useful for predicting the future exchange rate returns (Mark 1995, Mark and Sul, 2001).

The monetary model of exchange-rate determination suggests a strong link between the nominal exchange rate and monetary fundamentals. The monetary model implies that the price level of a country is determined by its supply and demand for money and that the price level in different countries should be the same when expressed in the same currency. This makes it an attractive theoretical tool for understanding fluctuations in exchange rates over time. It also provides a long-run benchmark for the nominal exchange rate between two currencies and thus a clear criterion for determining whether a currency is significantly „overvalued“" or „undervalued.“

The main objectives of our study are:

- To analyze the exchange rate determination by using the monetary model.

- To develop a modified monetary model and compare the actual and modified model of exchange rate determination.

- To test whether the dollarization influences the exchange rate or not.

The study is organized into five sections. In this section, introduction and objectives of the study are given. In the second section review of literature related to impact of exchange rate on economy will be discussed. In the third section, data and methodology is explained. In section four estimation and result are explained. Conclusion and policy implication are discussed in last section.

\section{Literature REVIEW}

Craig well, Wright and Singh (2009), examined the behavior of US/Jamaica exchange rate. They use the hybrid model that combines economic fundamental and micro-market variables. The main purpose of the paper is to test empirically a hybrid model of the Jamaica/US \$exchange rate, along the lines of Evans and Lyons (2001) who improved the traditional macroeconomic analysis by inserting a variable from market microstructure finance. The findings suggest that micro-market variables are important factors in the explaining US/Jamaica exchange rate movement, and that their omission may explain some the earlier failures of these empirical exchange rate equation.

Islam and Hasan (2006), examined the monetary model in determination of dollar-yen exchange rates by applying co-integration and granger causality methodology. The result indicated that stationery relationship between the dollar-yen exchange rate and monetary model, with long -term causality flowing from monetary variables to the dollar-yen exchange rates.

Dara long and samreth (2008), examined the validity of both short and long run monetary model exchange rate for the case of Philippines. It is concluded that money, income and interest rate are important factors for determining the exchange rate in the monetary model of exchange rate. Similarly, the result also suggested that it is inappropriate to assume that income and interest rate of domestic and foreign country have the same effects (in absolute value) when estimating exchange rate model.

Cavusoglu, investigated empirically the presence of any identifiable and reasonable long-run relationships among the variables of a system which is expected to reflect the exchange rate (TL/\$) dynamics in Turkey. The result suggested that conditioning the model on these weakly exogenous variables and imposing an economic structure through over-identification restrictions are not rejected and provide three long-run relations to be explained. The rate of inflation appears to be more influential on the nominal depreciation of the domestic currency than the direct effects from the money market, and has no feedback from the rate of depreciation. Moreover, there seems to be a feedback relationship between the rate of depreciation and nominal interest rate.

Civcir (2003), examined the validity of the monetary model of exchange rate determination as an explanation of the Turkish Lira-United States dollar relationship. The result suggested is in favor of the monetary model. The equilibrium relationships are used to construct an equilibrium measure of the lira. Results indicate that a sensible estimate about the equilibrium value of the lira/US dollar exchange rate can be obtained.

Liew,atel.(2009), examined the long-run relationship between exchange rate and its determinants based on the flexible-price monetary model. The study is to provide evidence favoring the long-run validity of this monetary model for the case of the Philippines also finds the predictive power of monetary model outperformed well. The empirical results provide evidence favoring the monetary approach to exchange rate for a small and open emerging economy, namely Thailand.

Nwafor (2006), examined whether the flexible price monetary model (FPMM) of exchange rate is consistent with the variability of the naira-dollar exchange rate. The results show at least one co-integrating 
vector, suggesting a long-run equilibrium relationship between the naira-dollar exchange rate and the FPMM fundamentals.

Barnett and Kwag (2005), worked to incorporate aggregation and index number theory into monetary models of exchange rate determination in a manner that is internally consistent with money market equilibrium. They estimate a flexible price monetary model, a sticky price monetary model, and the Hooper and Morton (1982) model for the US dollar/UK pound exchange rate. They find that models with Divisia indexes are better than the random walk assumption in explaining the exchange rate fluctuations.

\section{THEORETICAL MODEL:}

Absolute purchasing power parity (PPP) means "that exchange rate is equal to relative's price levels" (Krugraman, Obstfeld, 2000, P.397) and can be written as follows:

$$
e=P / p^{*}
$$

Where e is the nominal exchange rate, $\mathrm{P}$ and $\mathrm{P}^{*}$ are domestic and foreign price levels, respectively.

" while PPP concludes that the exchange rate is relatives price of goods in the two countries, monetary theory suggests that the exchange rate is the relatives price of two moneys" (Levich, 1983, P.32). So in the monetary approach exchange rate represented as relatives demand for money of two countries.

Let us express the demand for the real money balances $\left(\mathrm{M}^{\mathrm{d}} / \mathrm{P}\right)$ as:

$$
M^{d} / P=F(y, i, K)
$$

Where $\mathrm{M}$ denotes demand for money, $\mathrm{P}$ is the price levels, $\mathrm{L}$ is some function of real income( $\mathrm{Y})$, the interest rate(I), and others factors $(\mathrm{K})$ that determine money demand. Real money demand is positively related to the income and negatively related to the interest rate.

The demand for real money balances in equilibrium is equal to real money supply.

$M^{d} / P=M^{s} / p$

Where $\mathbf{M}^{\mathrm{s}}$ is money supply, (2) and (3) can be written as

$$
p=M^{s} / L(Y, i, K)
$$

Since money supply is equal to the money demand, prices can be expressed as

$$
P=M / L(Y, i, K)
$$

Where $\mathrm{M}$ is equilibrium quantity of money

Price level of foreign country can be presented as in the same way

$$
p=M * / L *\left(y^{*}, i^{*}, K^{*}\right)
$$

Where $*$ denotes the foreign country.

According to Lavish (1983, P.34) for the flexible price monetary model.

We can write money demand as

$$
M^{d} / p=Y^{\alpha} e^{-\beta i} K
$$

Where e is an exponent, and $\mathrm{Y}^{\alpha}$ and $-\beta_{\mathrm{i}}$ are elasticities of income and interest respectively.

$M^{d^{*}} / p^{*}=Y^{\alpha^{*}} e^{-\beta i^{*}} K^{*}$

Where $\mathrm{e}$ is an exponent, and $\mathrm{Y}^{\alpha^{*}}$ and $-\beta_{\mathrm{i}}^{*}$ are elasticities of income and interest respectively.

So, the following equation logic introduced above can be written as

$$
\begin{aligned}
& P=M / Y^{\alpha} e^{-\beta_{i}{ }^{i} i} K \\
& P^{*}=M^{*} / Y^{\alpha^{*}} e^{-\beta_{i} i{ }^{*}} K^{*}
\end{aligned}
$$

Putting equation (9) and (10) into (1), we will get

$e=\frac{M / Y^{\alpha} e^{-\beta_{i}} K}{M * / Y^{\alpha^{*}} e^{-\beta^{*}} K^{*}}$

$e=\frac{M}{Y^{\alpha} e^{-\beta_{i}} k} \times \frac{Y^{\alpha^{*}} e^{-\beta^{*}} K^{*}}{M^{*}}$

$e=\left(\frac{M}{M^{*}}\right)\left(\frac{Y^{\alpha^{*}}}{Y^{\alpha}}\right)\left(\frac{e^{-\beta^{*} i}}{e^{-\beta_{i}}}\right)\left(\frac{K^{*}}{K}\right)$

By taking log we have

$$
e=\left(m-m^{*}\right)+\left(\alpha^{*} Y^{*}-\alpha Y\right)+\left(-\beta i^{*}+\beta i\right)+\left(K^{*}-K\right)
$$


$e=m-m^{*}-\alpha Y+\alpha^{*} Y^{*}+\beta i-\beta i^{*}+K^{*}-K$

For simplicity suppose no other factor effecting money demand

So $K=K^{*}=0$

$$
e=m-m^{*}-\alpha Y+\alpha^{*} Y^{*}+\beta i-\beta i^{*}
$$

The above equation shows the monetary model for flexible prices. In case of monetary model for sticky price.

We have the equation like:

$e=m-m^{*}-\alpha y+\alpha^{*} y^{*}-\beta i+\beta i^{*}$

\section{Econometric specification of the model:}

In the econometric form we can write above equation as

$e_{t}=\gamma_{o}+\gamma_{1} m_{t}+\gamma_{2} m^{*}+\gamma_{3} y+\gamma_{4} y^{*}+\gamma_{5} i+\gamma_{6} i^{*}+\varepsilon_{t}$

Where $\gamma_{0}$ is a constant and $\varepsilon$ is an error term.

Since the basic monetary model does a not include variable that may be significant in explanation of exchange rate behavior like the dollarization ratio. So we introduce this ratio by substitution dollarization ratio instead of $\mathrm{K}$ in eq. (12). So in this case our modified model will be

$e_{t}=\gamma_{o}+\gamma_{1} m_{t}+\gamma_{2} m_{t}{ }^{*}+\gamma_{3} y_{t}+\gamma_{4} y_{t}{ }^{*}+\gamma_{5} i_{t}+\gamma_{6} i_{t}{ }^{*}+\gamma_{7} d r_{t}+\varepsilon_{t}$

Where $\mathrm{dr}$ is the dollarization ratio which is calculated by using the percentage ratio of deposits in foreign currency US dollar to all deposits.

This study undertakes the issue of exchange rate determination through monetary model. All those monetary variables is used which determine the exchange rate. Our model includes the following variables.

\section{Dependent variable}

$\mathrm{EX}=$ nominal exchange rate

Independent variables

$\mathrm{i}=$ Discount rate (domestic interest rate)

$i^{*}=$ federal fund rate (foreign interest rate)

$\mathrm{M}=$ domestic money supply

$\mathrm{M} *=$ foreign money supply

$\mathrm{Y}=$ real GDP domestic

$\mathrm{Y}^{*}=$ real GDP foreign

We take log of our data except the domestic and foreign interest rate, $\gamma$ is the parameters and

Co-efficient and $\varepsilon$ is the error term.

Regression (16) and (17) will be tested. They enable us to test the following hypothesis:

1. $\mathrm{H}_{\mathrm{o}}$ : Neither the basic nor the modified monetary model explains the ER in Pakistan.

$\mathrm{H}_{1}$ : Either the basic or the modified monetary model explains the ER in Pakistan.

2. $\mathrm{H}_{\mathrm{o}}$ : Dollarization does not influence the ER.

$\mathrm{H}_{1}$ : Dollarization influences the ER.

Data and Sources:

* In our study we use annual data from 1982 to 2009 covering 28 financial years to determined exchange rate through monetary model.

* Source of data:

$>$ International financial statistics (Pak)

$>$ International financial statistics (USA)

Unit Root Test:

\begin{tabular}{|c|c|c|c|c|c|c|}
\hline \multirow[t]{2}{*}{ variables } & \multirow[t]{2}{*}{ lags } & \multicolumn{2}{|c|}{ level } & \multirow[t]{2}{*}{ lags } & \multicolumn{2}{|c|}{$1^{\text {st }}$ difference } \\
\hline & & intercept & $\begin{array}{ll}\text { Trend } & \& \\
\text { intercept } & \end{array}$ & & intercept & Trend \& intercept \\
\hline ER & 1 & $\begin{array}{l}0.99 \\
(2.92)\end{array}$ & $\begin{array}{l}2.13 \\
(3.58)\end{array}$ & 0 & $\begin{array}{l}4.28 * \\
(2.97)\end{array}$ & $\begin{array}{l}4.60^{*} \\
(3.58)\end{array}$ \\
\hline $\mathrm{M}$ & 1 & $\begin{array}{l}0.6653 \\
(2.9705)\end{array}$ & $\begin{array}{l}3.8392 \\
(3.5867)\end{array}$ & 1 & $\begin{array}{l}3.7040^{*} \\
(2.9850)\end{array}$ & $\begin{array}{l}3.949358^{*} \\
(3.5943)\end{array}$ \\
\hline$M^{*}$ & 0 & 1.64 & 2.41 & 0 & $5.88 *$ & $5.10^{*}$ \\
\hline
\end{tabular}


What Determines the Behavior of Exchange Rate in Pakistan: Monetary Model Analysis

\begin{tabular}{|c|c|c|c|c|c|c|}
\hline & & $(2.97)$ & $(3.58)$ & & $(2.97)$ & $(3.58)$ \\
\hline $\mathrm{y}$ & 0 & $\begin{array}{l}0.400 \\
(2.97)\end{array}$ & $\begin{array}{l}2.24 \\
(3.58) \\
\end{array}$ & 0 & $\begin{array}{l}5.24^{*} \\
(2.97)\end{array}$ & $\begin{array}{l}5.10^{*} \\
(3.58)\end{array}$ \\
\hline $\mathrm{Y}^{*}$ & 0 & $\begin{array}{l}1.93 \\
(2.97)\end{array}$ & $\begin{array}{l}2.12 \\
(3.57)\end{array}$ & 0 & $\begin{array}{l}5.48^{*} \\
(2.97)\end{array}$ & $\begin{array}{l}5.60 * \\
(3.58)\end{array}$ \\
\hline $\mathrm{dr}$ & 0 & $\begin{array}{l}0.42 \\
(2.97)\end{array}$ & $\begin{array}{l}2.06 \\
(3.57)\end{array}$ & 0 & $\begin{array}{l}5.20 * \\
(2.97)\end{array}$ & $\begin{array}{l}5.17 * \\
(3.58)\end{array}$ \\
\hline $\mathrm{r}$ & 1 & $\begin{array}{l}2.917465 \\
(2.9750)\end{array}$ & $\begin{array}{l}2.791300 \\
(3.5867)\end{array}$ & 0 & $\begin{array}{l}4.1374 * \\
(2.9750)\end{array}$ & $\begin{array}{l}4.1131^{*} \\
(3.5867)\end{array}$ \\
\hline$r^{*}$ & 2 & $\begin{array}{l}0.181602 \\
(2.9798)\end{array}$ & $\begin{array}{l}0.22 \\
(3.67)\end{array}$ & 1 & $\begin{array}{l}2.6422^{*} \\
(1.9546)\end{array}$ & $\begin{array}{l}2.440511^{*} \\
(3.5943)\end{array}$ \\
\hline
\end{tabular}

To examine whether a time series have unit root we have used Augmented Dickey-Fuller (ADF) unit root test. The *on the value shows that the values are stationary at $5 \%$ level of significance. All the variables are stationary at $1^{\text {st }}$ difference. Therefore the most appropriate technique is Co-integration. The first step of this test is to estimate the VAR to choose the lag length of the model. The maximum lag length of our model is 1 . For the estimation of equation 16 we are using the trace statistic and Max-Eigen Statistic in order to find the long run relationships. By using the Trace Statistic we have the following results.

Trace test indicates 5 co-integrating eq(s) at the 0.05 level

$*$ denotes rejection of the hypothesis at the 0.05 level

By using the Max-Eigen Statistic we have the following results

\begin{tabular}{|l|l|l|l|l|l|}
\hline Ho & H1 & Eigen Values & $\begin{array}{l}\text { Max-Eigen } \\
\text { Statistic }\end{array}$ & Critcal Values(0.05) & Probability \\
\hline $\mathrm{r}=0^{*}$ & $\mathrm{r}=1$ & 0.982598 & 105.3300 & 47.07897 & 0.0000 \\
\hline $\mathrm{r} \leq 1^{*}$ & $\mathrm{r}=2$ & 0.908147 & 62.07672 & 40.95680 & 0.0001 \\
\hline $\mathrm{r} \leq 2^{*}$ & $\mathrm{r}=3$ & 0.753442 & 36.40414 & 34.80587 & 0.0319 \\
\hline $\mathrm{r} \leq 3^{*}$ & $\mathrm{r}=4$ & 0.590118 & 23.18904 & 28.58808 & 0.2101 \\
\hline $\mathrm{r} \leq 4^{*}$ & $\mathrm{r}=5$ & 0.521100 & 19.14283 & 22.29962 & 0.1303 \\
\hline $\mathrm{r} \leq 5$ & $\mathrm{r}=6$ & 0.368107 & 11.93493 & 15.89210 & 0.1898 \\
\hline $\mathrm{r} \leq 6$ & $\mathrm{r}=7$ & 0.209248 & 6.104040 & 9.164546 & 0.1829 \\
\hline
\end{tabular}

Max-eigenvalue test indicates 5 co-integrating eq.(s) at the 0.05 level

* denotes rejection of the hypothesis at the 0.05 level.

\section{Estimated Co-integrated Coefficients:}

Dependent variable: ER

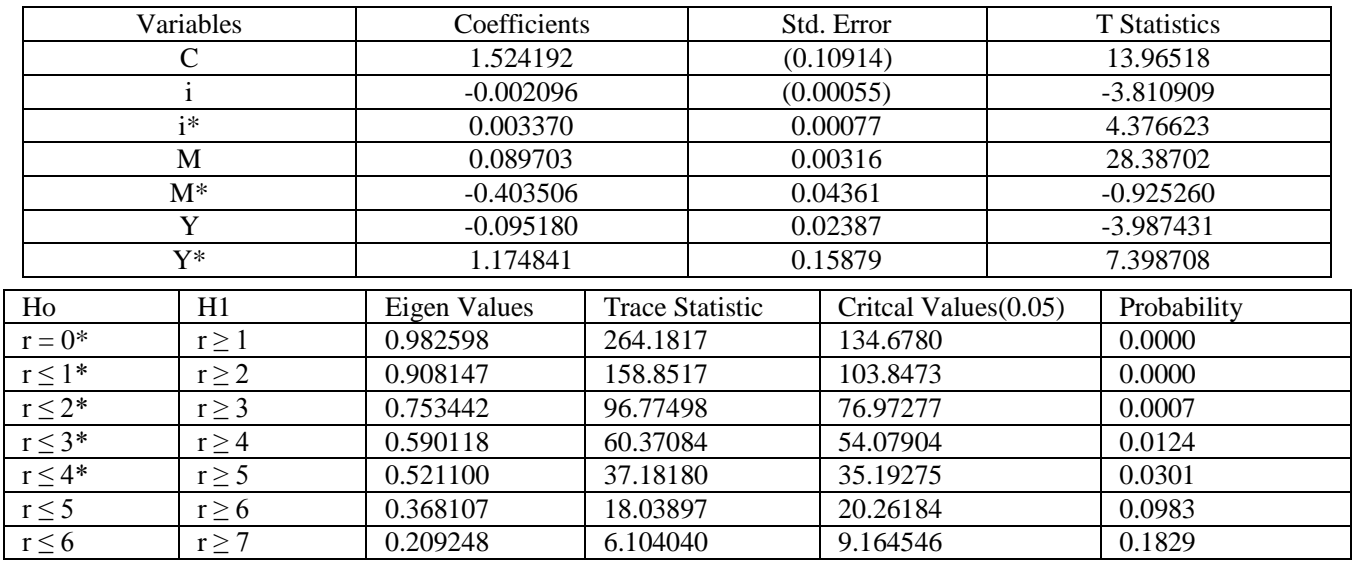

Equation 16 shows the exact relationship between the variables. Domestic interest has negative relationship with the exchange rate and has significant impact on the exchange rate. One percent increase in the domestic interest will lead to 0.002 decreases in the exchange rate. While the foreign interest has a positive relationship with the exchange rate, one percent increase in the foreign interest rate will lead to 0.003 increases in the exchange rate and has significant values.

Domestic money supply has positive relationship with the exchange rate and has significant impact on the exchange rate. One percent increases in the money supply domestically will lead to 0.08 increases in the exchange rate. Foreign money supply has negative relationship with the exchange rate which means one percent increase in the foreign money supply will lead to 0.4 percent decrease in the exchange rate and has insignificant impact. 
Domestic income has negative impact on the exchange rate which means one percent increase in the domestic income lead to 0.09 decreases in the exchange rate and has significant impact. On the other hand foreign income has positive and significant impact on the exchange rate which means one percent increase in the foreign income lead to 1.17 percent increase in the exchange rate.

\section{Diagnostic Tests:}

\begin{tabular}{|l|l|}
\hline White Heterosacdasticity Test $\left(\mathrm{N}^{*} \mathrm{R}^{2}\right)$ & 2.572861 (Prob.0.0515) \\
\hline Ramsay RESET Test (F- Statistics) & 8.076651 (Prob. 0.0601) \\
\hline Jarque Bera Test & 1.575365 (Prob. 0.4548) \\
\hline
\end{tabular}

In the diagnostic test we check the hetrosecdasticity test which shows that there is no problem of hetro problem in the equation. In order to check that whether the model is correctly specified or not we use the Romsay RESET test under the null hypothesis of correctly specified model. The result shows that our calculated value of $\mathrm{F}$ is less than the tabulated value. So we accept our null hypothesis and conclude that our model is correctly specified. Jarque Bera normality test is used under the null hypothesis that errors are normally distributed. The results show that errors are normally distributed because the value of Jarque Bera is less than $\chi^{2}$ value.

\section{Stability Test:}

In order to test the stability we use the CUSUM test. The result shows that the specific model is stable because the estimated line lies between the two critical lines.

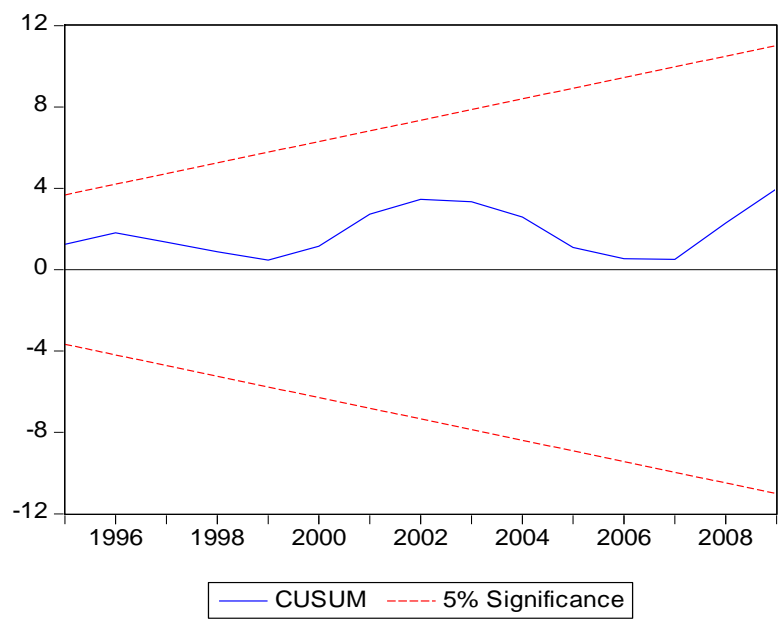

Short Run Analysis:

\begin{tabular}{|l|l|l|l|}
\hline Variables & Coefficients & Std. Errors & T- Statistics \\
\hline $\mathrm{D}(\mathrm{i}(-1))$ & -0.001064 & 0.01184 & -0.08989 \\
\hline $\mathrm{D}\left(\mathrm{i}^{*}(-1)\right)$ & 0.024712 & $0.02013)$ & 1.22780 \\
\hline $\mathrm{D}(\mathrm{M}(-1))$ & 0.012767 & 0.04995 & 0.25561 \\
\hline $\mathrm{D}\left(\mathrm{M}^{*}(-1)\right)$ & -0.212185 & 0.97946 & -0.21663 \\
\hline $\mathrm{D}(\mathrm{Y}(-1))$ & -0.805757 & 0.45519 & -1.77016 \\
\hline $\mathrm{D}\left(\mathrm{Y}^{*}(-1)\right)$ & 1.322743 & 1.34025 & 0.98694 \\
\hline $\mathrm{ECT}(-1)$ & -0.380728 & 1.22346 & -1.31119 \\
\hline
\end{tabular}

In the short run analysis the domestic interest, foreign money and domestic income has negative impact on the exchange rate. Domestic money supply, foreign interest rate and foreign income are positively related with the exchange rate. Error correction term is 0.38 which shows that it is $38 \%$ adjusted in this year.

For the estimation of equation 17 we are using the trace statistic and Max-Eigen Statistic in order to find the long run relationships. 
Trace statistic Test:

Trace test indicates 5 cointegrating eqn(s) at the 0.05 level

\begin{tabular}{|l|l|l|l|l|l|}
\hline Ho & $\mathrm{H} 1$ & Eigen Values & Trace Statistic & Critcal Values(0.05) & Probability \\
\hline $\mathrm{r}=0^{*}$ & $\mathrm{r} \geq 1$ & 0.987334 & 352.4352 & 159.5297 & 0.0000 \\
\hline $\mathrm{r} \leq 1^{*}$ & $\mathrm{r} \geq 2$ & 0.949153 & 238.8462 & 125.6154 & 0.0000 \\
\hline $\mathrm{r} \leq 2^{*}$ & $\mathrm{r} \geq 3$ & 0.915575 & 161.3940 & 95.75366 & 0.0000 \\
\hline $\mathrm{r} \leq 3^{*}$ & $\mathrm{r} \geq 4$ & 0.845969 & 97.12479 & 69.81889 & 0.0001 \\
\hline $\mathrm{r} \leq 4^{*}$ & $\mathrm{r} \geq 5$ & 0.655558 & 48.48914 & 47.85613 & 0.0435 \\
\hline $\mathrm{r} \leq 5$ & $\mathrm{r} \geq 6$ & 0.385501 & 20.77757 & 29.79707 & 0.3717 \\
\hline $\mathrm{r} \leq 6$ & $\mathrm{r} \geq 7$ & 0.267713 & 8.116908 & 15.49471 & 0.4530 \\
\hline $\mathrm{r} \leq 7$ & $\mathrm{r} \geq 8$ & 0.000605 & 0.015743 & 3.841466 & 0.9000 \\
\hline
\end{tabular}

$*$ denotes rejection of the hypothesis at the 0.05 level

Max-Eigenvalue Test:

Max-eigenvalue test indicates 5 cointegrating eqn(s) at the 0.05 level

\begin{tabular}{|l|l|l|l|l|l|}
\hline Ho & $\mathrm{H} 1$ & Eigen Values & Max-Eigen Statistic & Critcal Values(0.05) & Probability \\
\hline $\mathrm{r}=0^{*}$ & $\mathrm{r}=1$ & 0.987334 & 113.5890 & 52.36261 & 0.0000 \\
\hline $\mathrm{r} \leq 1^{*}$ & $\mathrm{r}=2$ & 0.949153 & 77.45222 & 46.23142 & 0.0000 \\
\hline $\mathrm{r} \leq 2^{*}$ & $\mathrm{r}=3$ & 0.915575 & 64.26916 & 40.07757 & 0.0000 \\
\hline $\mathrm{r} \leq 3^{*}$ & $\mathrm{r}=4$ & 0.845969 & 48.63565 & 33.87687 & 0.0005 \\
\hline $\mathrm{r} \leq 4^{*}$ & $\mathrm{r}=5$ & 0.655558 & 27.71157 & 27.58434 & 0.0482 \\
\hline $\mathrm{r} \leq 5$ & $\mathrm{r}=6$ & 0.385501 & 12.66067 & 21.13162 & 0.4839 \\
\hline $\mathrm{r} \leq 6$ & $\mathrm{r}=7$ & 0.267713 & 8.101165 & 14.26460 & 0.3685 \\
\hline $\mathrm{r} \leq 7$ & $\mathrm{r} \geq 8$ & 0.000605 & 0.015743 & 3.841466 & 0.9000 \\
\hline
\end{tabular}

$*$ denotes rejection of the hypothesis at the 0.05 level

\section{Estimated Co integrated Coefficients}

Dependent Variable: ER

\begin{tabular}{|l|l|l|l|}
\hline Variables & Coefficients & Std. Error & T Statistics \\
\hline $\mathrm{C}$ & 1.524192 & $(0.10914)$ & 13.96518 \\
\hline $\mathrm{i}$ & -0.003332 & $(0.00065)$ & -5.12615 \\
\hline $\mathrm{i}^{*}$ & 0.007052 & 0.00079 & 8.92658 \\
\hline $\mathrm{M}$ & 0.100644 & 0.04322 & 2.32864 \\
\hline $\mathrm{M}^{*}$ & -0.411416 & 0.05019 & -8.197170 \\
\hline $\mathrm{Y}$ & -0.056126 & 0.02699 & -2.079510 \\
\hline $\mathrm{Y}^{*}$ & 1.140087 & 0.15159 & 7.520858 \\
\hline $\mathrm{dr}$ & 0.16435 & 0.0829 & 1.985431 \\
\hline
\end{tabular}

Domestic interest has negative relationship with the exchange rate and has significant impact on the exchange rate. One percent increase in the domestic interest will lead to 0.003 percent decreases in the exchange rate. While the foreign interest has a positive relationship with the exchange rate, one percent increase in the foreign interest rate will lead to 0.007 percent increases in the exchange rate and has significant values.

Domestic money supply has positive relationship with the exchange rate and has significant impact on the exchange rate. One percent increases in the money supply domestically will lead to 0.100 increases in the exchange rate. Foreign money supply has negative relationship with the exchange rate which means one percent increase in the foreign money supply will lead to 0.4 percent decreases in the exchange rate and has significant impact.

Domestic income has negative impact on the exchange rate which means one percent increase in the domestic income lead to 0.56 percent decreases in the exchange rate and has significant impact. On the other hand foreign income has positive and significant impact on the exchange rate which means one percent increase in the foreign income lead to 1.14 percent increase in the exchange rate. Dollarization has positive relationship with the exchange rate and has significant impact. It means one percent increase in dollarization leads to 0.164 percent increases in the exchange rate. So we can say that the modified monetary model is better than actual model because dollarization has significant impact on exchange rate. 


\section{Diagnostic Tests:}

\begin{tabular}{|l|l|}
\hline White Heterosacdasticity Test $\left(\mathrm{N} * \mathrm{R}^{2}\right)$ & 8.655529 (Prob.0.27832) \\
\hline Ramsay RESET Test (F- Statistics) & 3.931803 (Prob. 0.0620) \\
\hline Jarque Bera Test & 2.08594 (Prob. 0.35226) \\
\hline
\end{tabular}

In the diagnostic test we check the hetrosecdasticity test which shows that there is no problem of hetro problem in the equation. In order to check that whether the model is correctly specified or not we use the Romsay RESET test under the null hypothesis of correctly specified model. The result shows that our calculated value of $\mathrm{F}$ is less than the tabulated value. So we accept our null hypothesis and conclude that our model is correctly specified. Jarque Bera normality test is used under the null hypothesis that errors are normally distributed. The results show that errors are normally distributed because the value of Jarque Bera is less than $\chi^{2}$ value.

Stability Test:

In order to test the stability we use the CUSUM test. The result shows that the specific model is stable because the estimated line lies between the two critical lines.

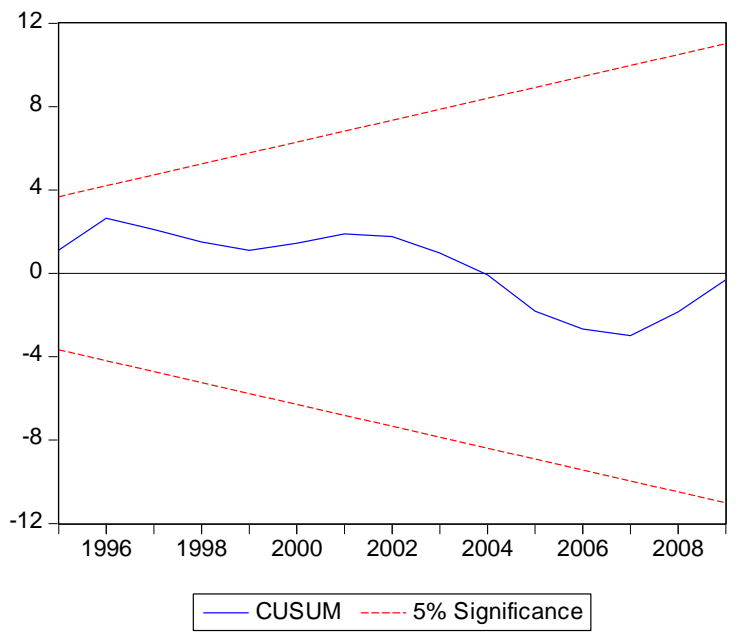

Short Run Analysis:

\begin{tabular}{|l|l|l|l|}
\hline Variables & Coefficients & Std. Errors & T- Statistics \\
\hline $\mathrm{C}$ & 0.154221 & 0.05286 & 2.91775 \\
\hline $\mathrm{D}(\mathrm{i}(-1))$ & -0.003153 & 0.00878 & -0.35909 \\
\hline $\mathrm{D}\left(\mathrm{i}^{*}(-1)\right)$ & 0.021111 & 0.01355 & 1.55764 \\
\hline $\mathrm{D}(\mathrm{M}(-1))$ & 0.003429 & 0.04806 & 0.07135 \\
\hline $\mathrm{D}\left(\mathrm{M}^{*}(-1)\right)$ & -1.910155 & 0.98161 & -1.94594 \\
\hline $\mathrm{D}(\mathrm{Y}(-1))$ & -0.562676 & 0.46534 & -1.20916 \\
\hline $\mathrm{D}\left(\mathrm{Y}^{*}(-1)\right)$ & 1.745129 & 1.01912 & 1.71239 \\
\hline $\mathrm{D}(\mathrm{RG}(-1))$ & 0.039528 & 0.03244 & 1.21868 \\
\hline $\mathrm{ECT}(-1)$ & -0.747257 & 0.38116 & -1.96046 \\
\hline
\end{tabular}

In the short run analysis the domestic interest has negative impact on the exchange rate and has insignificant $t$ values. It means if one percent increase in domestic interest rate lead to 0.003 decreases in the exchange rate. On the other hand foreign interest has positive relationship with the exchange rate. Domestic money supply is positively related with the exchange rate but has insignificant impact. On the other hand foreign money supply has negative relationship with the exchange rate one percent increase in the domestic income lead to 0.56 decreases in the exchange rate. Foreign income is positively related with the exchange rate and has insignificant impact. Dollarization is positively related with the exchange rate and has significant impact on the exchange rate at the 10 percent level of significance. One percent increase in the dollarization lead to 0.039 percent increase in the exchange rate. Error correction term is 0.74 which shows that $74 \%$ errors are adjusted. 


\section{CONCLUSION:}

Many valuable case studies have been done to determine the exchange rate through different methods. This study has been attempted to determine the exchange through the monetary model. The empirical analysis is based on the time-series data for Pakistan over the period 1982 to 2009. Most of the data has been derived from IFS and hand book of state bank of Pakistan and unit root and co-integration tests are applied for the estimation. We also analyze the effect of the explanatory variables i.e. (domestic discount rate, foreign federal fund rate, domestic money supply, foreign money supply, domestic income, foreign income and reserve minus gold) on the exchange rate of Pakistan. The results described in the previous section have led to the following conclusions. In long run results of co-integration applied on the equation shows that domestic interest rate has negative relationship with the exchange rate, while the foreign interest rate has positive relationship with the exchange rate. Domestic money supply has positive relationship with the exchange rate and foreign money supply is negatively related with the exchange rate. Domestic income is negatively and foreign income is positively related with the exchange. In equation 2 dollarization is positively related with the exchange rate. In short run all the variable is negatively related with the exchange rate except foreign interest, foreign income and domestic money supply and dollarization.

We applied different diagnostic tests which show that the model is correctly specified and there is no problem of hetro in our model. CUSUM and CUSUM square test is used to test the stability of the model. The test shows that the model is stable.

- In the light of our result we can say that we should focus on the modified monetary instead of simple model because dollarization is an important factor in the determination of exchange rate. Thus exchange rate policy has to be selected taking into account high degree of dollarization.

- Money supply can be employed as a tool to influence the exchange rate, while great caution should be exercised with regard to interest rate since it reflects inflationary expectations.

\section{Direction for further study:}

The basic and modified model can be tested for other currencies like Euro, Pound for the exchange rate determination.

\section{References}

[1]. Barnet and kwag (2005),"Exchange Rate Determination from monetary fundamental: An aggregation theoretic approach", Forthcoming in Frontier in Finance and Economics, December 1992.

[2]. Zhang, Shidang, Lowinger and Thomas C (2005),"Co-integration in a monetary model of exchange rate determination", ASBBEJournal Vol.1, No.1

[3]. McDonald, Ronald and Taylor (1994),"'The monetary model of the exchange rate: Long-Run Relationship, Short-Run Dynamics and how to beat a random walk:" journal of international money and finance 13(3pp.276-290),

[4]. Bhatti (2001),'Determining Pak Rupee Exchange Rate Vis-a-Vis Six currencies of the industrial world: some Evidence Based on traditional flow model", The Pakistan development review 40:4 part-II (winter 2001) pp.885-897.

[5]. Mohammad and Lal (2010),"'The Euro-Dollar exchange rate and Pakistan economy", European journal of scientific research, vol.42, no.1, pp6-15.

[6]. Khan and qayyum (2007),"exchange rate determination in Pakistan: evidence based on purchasing power parity theory", Pakistan economic and social review, vol.45, No.2 (winter 2007), pp.181-202.

[7]. Frenkel J.A (1980),"exchange rate, prices and money: Lessons from the 1920,"The American economic review, Vol.70, no.2, pp.235-242.

[8]. Johanston and Scott, "Exchange rate probability distributions and fundamentals variables, "Journal of finance strategic decision, vol.10, no.2.

[9]. Civcir (2003),"the monetary model of exchange rate under high inflation: the case of the Turkish lira/us Dollar," Czech Journal of economics and finance, vol.53, pp.3-4.

[10]. Nwafor (2006),"'The Naira-Dollar Exchange Rate Determination: A Monetary Perspective", International Research Journal of Finance and Economics.

[11]. Civcir (2003)," The Long-run Validity of Monetary Exchange Rate Model for a High Inflation Country and Misalignment: The Case of Turkey" Forthcoming in Russian and East European Finance and Trade,

[12]. Francis, B. et al (2001) "The Monetary Approach to Exchange Rates and the Behavior of the

[13]. Canadian Dollar over the Long Run" Applied Financial Economics 11, 475-81.

[14]. Francis, Bill, Hansan, Iftekhar and Lothian, James (2001). "The Monetary Approach to Exchange Rates and the Behavior of the Canadian Dollar over the long run."Applied Financial Economics,

[15]. Volume 11, issue 5, Pages 475-481.

[16]. Groen, Jan (2000). “(Euro) Exchange Rate Predictability and Monetary Fundamentals in a Small Multi-Country Panel."Working Paper, Bank of England.

[17]. Dornbusch, R. (1976), "Expectations and Exchange Rate Dynamics," Journal of Political Economy 84, 1161-1176.

[18]. Bilson, J. (1978) The Monetary Approach to the Exchange Rate: Some Evidence. IMF Staff Papers 25, 48-75.

[19]. Branson, W. H. (1983) Macroeconomic Determinants of Real Exchange Risk. In R. 